\title{
PODRIJETLO VODE I NJENO ZNAČENJE NA PLANETI ZEMLJI
}

\section{THE ORIGIN OF WATER AND ITS MEANING FOR PLANET EARTH}

\author{
Elvis Žic ${ }^{*}$, Dejan Vasović ${ }^{* *}$
}

\begin{abstract}
Sažetak
U radu je dan opis podrijetla vode na planeti Zemlji i njezino značenje u prošlosti i sadašnjosti. Analizirani su razmjeri kretanja vode na zemlji, njihove značajke, kao i glavni izvori dostupne vode na zemlji izraženi kroz postotni udio na globalnoj razini. Također je razmatran nastanak vode u Svemiru i proizvodnja kisika u ranoj fazi nastanka planeta. Fokus rada bazira se na održanju kvalitete vode dostupne na Zemlji te pojavi globalne varijabilnosti intenziteta oborina koje u zadnjih nekoliko desetljeća mijenjaju značajke velikih svjetskih površina kroz procese velikih suša i poplava. Kroz rad su opisani neki od najznačajnijih primjera eksploatacije pitkih voda u svijetu kroz površinske i podzemne rezerve vode. Analizirane su mogućnosti povećanja proizvodnje hrane za ljudske potrebe u pogledu povećanja zemljišta kroz tehnološki napredne metode te zaštita vodnih resursa uslijed klimatskih promjena. Dan je osvrt na značajke kvalitete prirodne vode u medicini i industriji, poboljšanje sanitarnih uvjeta, utjecaj ljudskog zagađenje na globalnoj razini, gospodarski rast $i$ problem smanjenja vode, kao i globalni problem ispuštanja nepročišćenih otpadnih voda u recipijente $i$, posljedično, ugrožavanje flore i faune.
\end{abstract}

Ključne riječi: voda, podrijetlo vode, kvaliteta i kvantiteta vode, globalno zagađenje, klimatske promjene, metode zaštite

\section{Abstract}

This paper gives a description of the origin of water on planet Earth and its importance in the past and the present. The paper presents the analysis of water

\footnotetext{
* Sveučilište u Rijeci, Građevinski fakultet, Radmile Matejčić 3, 51000 Rijeka E-mail: elvis.zic@uniri.hr

** Fakultet zaštite na radu, Sveučilište u Nišu, Čarnojevića 10A, 18000 Niš

Email: dejan.vasovic@znrfak.ni.ac.rs
} 
flow extent on Earth, its characteristics, as well as the main sources of available water on the planet, expressed through a percentage share on a global scale. It also deals with the origin of water in the Universe, as well as the production of oxygen at the early stages of the planet's formation. The focus of the paper is based on maintaining the quality of water available on Earth and the global variability of precipitation intensity that has changed the characteristics of large world surfaces through significant drought and flood processes over the last decades. Throughout the paper, some of the most important examples of exploitation of drinking water in the world through the surface and underground reserves of water are described. The possibilities of increasing the production of food for human needs in terms of increasing land through technologically advanced methods and the protection of water resources due to climate change are analyzed. At the end of the paper, there is a review of the characteristics of natural water quality in medicine and industry, sanitary conditions improvement, the impact of global pollution on human beings, economic growth and the problem of water scarcity, as well as the global problem of discharging untreated wastewater into the recipients and consequently endangering flora and fauna.

Key words: water, water origin, quality and quantity of water, global pollution, climate change, protection methods

\section{Uvod}

Čudesna priroda vode $\mathrm{u}$ prošlosti je nadahnjivala mnoge pjesnike, slikare, skladatelje i filozofe. Voda je bila jedna od četiriju Aristotelovih elemenata pa se, dugo nakon što su zemlja, vatra i zrak bili prepoznati, voda još uvijek smatrala elementom. Tek su krajem 18. stoljeća Lavoisier i Priestley prikazali vodu kao „mješavinu“ elemenata. Prije otprilike petsto godina Leonardo da Vinci je objavio svoju knjigu "Del moto e misura dell'acqua" (O kretanju i mjerenju vode) u kojoj je opisao sofisticirana istraživanja fizičkih svojstava vode. Mnogi današnji znanstvenici i tehnolozi uzimaju značenje vode „zdravo za gotovo“ i rijetko poštuju njezinu jedinstvenu ulogu za oblikovanje našeg zemaljskog okruženja, čineći ga prikladnim za život.

Inženjeri drevne antike imali su mogućnost da svojim gradovima osiguraju vodu odgovarajuće kvalitete. Vodoprivreda je cvjetala tijekom Rimskog Carstva, a brojni akvadukti izgrađeni u to vrijeme postoje još i danas [1,2]. Praktično poznavanje svojstava gustoće vode, hlapljivosti i viskoznosti prethodilo je razvoju znanstvenog razumijevanja. Danas, svojstva vode igraju ključnu ulogu u oceanografiji i limnologiji, hidraulici, biokemiji i fizikalnoj kemiji. Znanstvenici još dan danas nisu jasno razmotrili konsenzus glede vjerodostojnog molekularnog opisa tekuće vode. Iako je u posljednjih nekoliko godina došlo do značajnog napretka, 
očigledno je da, unatoč svojoj molekularnoj jednostavnosti, voda u tekućem stanju još uvijek predstavlja veliku zagonetku. Voda se može tretirati kao trodimenzionalna mreža vezana vodikom, pri čemu dužine veza i kutovi porastom temperature postaju sve izobličeniji, ali bez značajnog broja nevezanih $\mathrm{H}_{2} \mathrm{O}$ molekula [3,5]. U zadnje vrijeme se veliki značaj pridaje istraživanjima čudnog ponašanja pothlađene i staklaste vode. Mnoga istraživanja u velikoj se mjeri oslanjaju na metode računalne simulacije i probnih područja P-V-T prostora (prostora tlaka-volumena-temperature).

\section{Podrijetlo i distribucija vode u ekosferi}

Voda je jedina anorganska tekućina koja se prirodno pojavljuje na Zemlji i jedini kemijski spoj koji se prirodno pojavljuje u sva tri agregatna stanja u ekosferi: krutom, tekućem i plinovitom. Oblik života na našem planetu evoluirao je prije 3,5 milijarda godina (predstanični oblici koji nisu imali sve karakteristike stanice, ali su ostvarili mehanizme za daljnje razmnožavanje uz pomoć nukleinskih kiselina), a stvarni život se razvio u vodi. Stoga je nastao pojam „životno prirodno ili poželjno stanište“, iz kojeg su se razvili utjecaji na mnoge biokemijske i fiziološke procese koji su uključeni u održivost živih organizama. Sa sigurnošću se može pretpostaviti da prisutnost vode u tekućem stanju može potjecati samo iz vremena kada je temperatura Zemljine kore pala ispod kritične temperature vode od $374^{\circ} \mathrm{C}$. Ukoliko je sva voda koja sada čini oceane postojala kao superkritična atmosfera vode, tada bi tlak po kvadratnom metru zemljine površine bio $25 \mathrm{MPa}[3,8]$. Tijekom hlađenja ispod kritične točke, ogromne mase vode su se kondenzirale na površini zemlje i prodirale duboko u stijene kroz pukotine. Dio te vode odmah bi se ponovno "prokuhao“ te se naknadno obnovio. Hidrološki ciklus isparavanja-kondenzacije mogao je stoga početi prije nekoliko milijardi godina. Stoga nije toliko važno je li toplina same zemlje ili sunčevog zračenja inicirala hidrološki ciklus, već je bitan razmjer kretanja vode. Ukupni sadržaj vode u atmosferi iznosi oko $60000 \mathrm{~km}^{3}$, a budući da je ukupna godišnja količina oborine oko $2250000 \mathrm{~km}^{3}$, voda se u atmosferi izmjenjuje oko 37 puta godišnje [3,9]. Ova razina oborine je ekvivalentna dubini vode od $0,5 \mathrm{~m}$ prosječno iznad površine Zemlje. Prostorna raspodjela ukupnih godišnjih količina oborina je neujednačena.

Prikaz hidrološkog ciklusa na planeti Zemlji dan je na Slici 1. Toplina sunca uzrokuje isparavanje vode. Pod utjecajem određenih promjena temperature i/ili tlaka vlaga se kondenzira i vraća na zemlju u obliku kiše, tuče, susnježice ili snijega (tzv. vode meteorskog podrijetla). Od prosječne količine oborina isparava oko $70 \%$, a ostatak se pojavljuje kao tekuća voda na ili ispod površine zemlje $[3,6]$. Pojedina količina vode isparava u zraku između oblaka i kopnene površine. Preostali gubici su predstavljeni kroz 
izravno isparavanje s vlažnih površina i transpiraciju kroz biljke iz njihovih listova i stabljika. Gotovo $30 \%$ vode koja se ne vraća izravno u atmosferu čini otjecanje i osigurava potencijalno dostupnu slatku vodu (Tablica 1.). Udio ukupnih slatkovodnih resursa Zemlje ne prelazi 0,003 \% (ostatak je zarobljen u antarktičkoj ledenoj kapi). Otapanjem tog leda, voda koja bi pritom nastala bi opskrbljivala sve zemaljske rijeke narednih 850 godina.

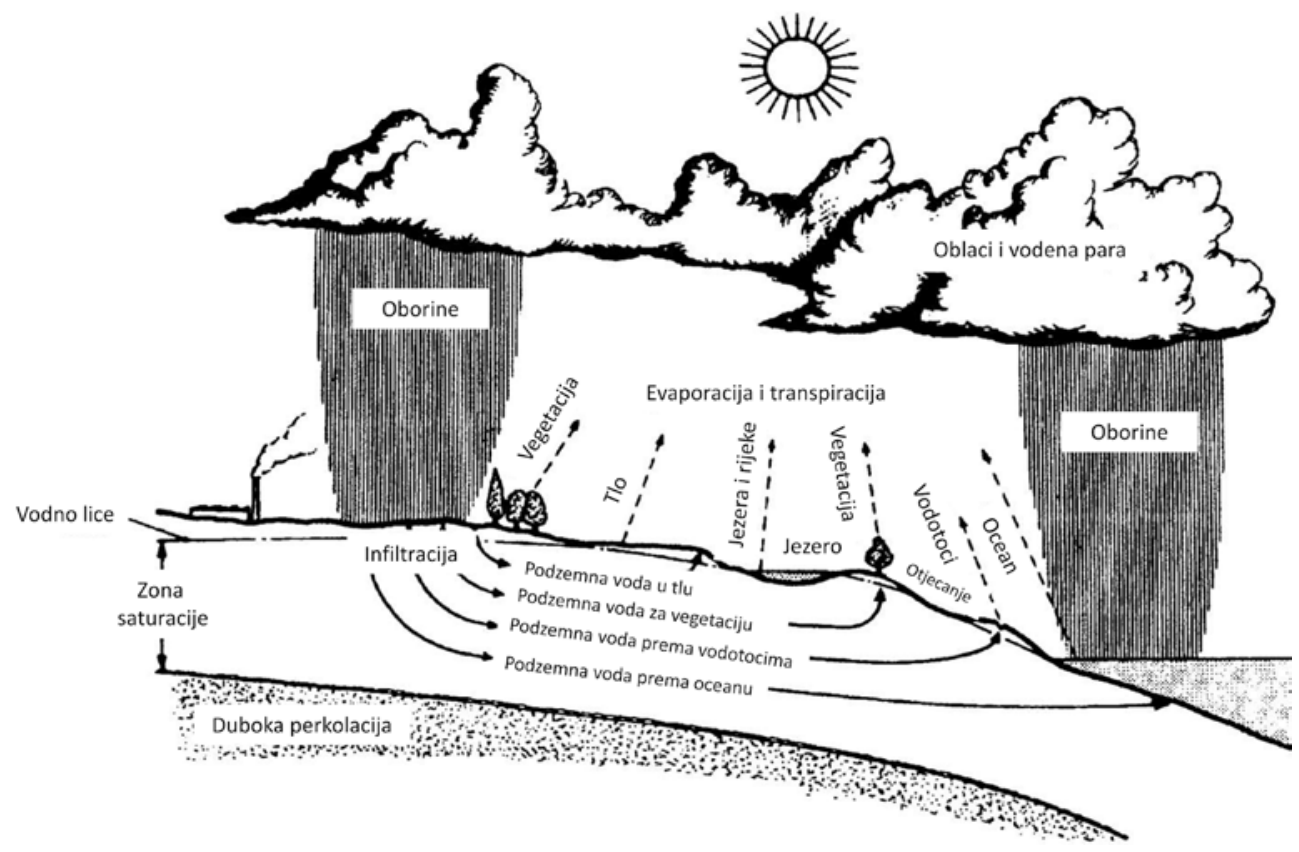

Slika 1. Shematski prikaz hidrološkog ciklusa, modificirano prema [3]

Tablica 1. Raspodjela i kretanje vodnih resursa na Zemlji (u $\mathrm{km}^{3}$ i \%), [3,4]

\begin{tabular}{|l|r|l|r|}
\hline Rijeke & $1200\left(9 \cdot 10^{-5} \%\right)$ & Arktička ledena kapa & $3000000(0,224 \%)$ \\
\hline Gornji sloj tla & $25000(0,00187 \%)$ & Antarktička ledena kapa & $30000000(2,239 \%)$ \\
\hline Godišnje otjecanje & $34000(0,00254 \%)$ & Godišnje oborine & $2000000(0,1493 \%)$ \\
\hline Jezera & $100000(0,00746 \%)$ & Vlaga u atmosferi & $60000(0,0045 \%)$ \\
\hline Ledenjaci & $200000(0,01493 \%)$ & Fotosinteza (godišnje) & $100\left(7,46 \cdot 10^{-6} \%\right)$ \\
\hline $\begin{array}{l}\text { Svježa podzemna } \\
\text { voda (1 km dubine) }\end{array}$ & $4000000(0,2986 \%)$ & Oceani & $1300000000(97,057 \%)$ \\
\hline
\end{tabular}

Najvažniji izvor sirove dostupne vode je kiša, čija je distribucija prilično neujednačena. Kao posljedica oborina i procjeđivanja od podzemne vode do površinskog sloja tla, ukupna količina vlage u tlu iznosi $25000 \mathrm{~km}^{3}$. Biljke normalno rastu na onome što se smatra „suhim“ kopnom, no to je pogrešan 
naziv, jer čak i pustinjski pijesak sadrži do $15 \%$ vode. Obično stablo prosječne veličine "povuče“ i transpirira oko 190 litara vode dnevno $[3,10]$. Kroz potoke i jezera dolazi manje od $3 \%$ svježe vode na Zemlji. Vlastite vode u vodotocima Republike Hrvatske sadrže $26,08 \cdot 10^{9} \mathrm{~m}^{3} /$ god., odnosno $156,32 \cdot 10^{9} \mathrm{~m}^{3} /$ god. ako se vlastitim vodama pribroje i vode koje nailaze iz susjednih zemalja (tzv. tranzitne vode) [4]. Dok se većina tekuće vode javlja u oceanima $\left(10^{21} \mathrm{~kg}\right)$, samo na Antarktičkom kontinentu nalazi se $10^{19} \mathrm{~kg}$ leda i snijega koji čine 99,997 \% svježe vode na planeti. Prema riječima Hiroshia Sugae, velikog istraživača leda, kada bi se cijeli taj led istopio i ravnomjerno rasporedio među svjetskom populacijom, tada bi svaka osoba imala dovoljno da napuni vodom oko 4000 olimpijskih bazena [3].

\section{Voda i razvoj života}

Proučavanje podrijetla vode u svemiru i prapovijesne promjene koje su se možda dogodile u sastavu naše atmosfere i hidrosfere rezultiraju fascinantnim zapažanjima. Potraga za vodom postala je važan aspekt istraživanja svemira. Postojanje leda u mnogim hladnim zvijezdama i meteoritima sada je čvrsto dokazano. U načelu, tamo gdje led postoji u izvanzemaljskom hladnom okruženju, također bi trebao postojati dokaz vodene pare budući da led ima konačni tlak sublimacije. Vodena para je otkrivena na Mjesecu te na planetima Marsu, Jupiteru i Saturnu [5,10].

Za svaku raspravu o životu na zemlji vrlo je važno utvrditi kada i kako se molekularni kisik pojavio prvi puta. Rani prokarioti imali su minimalne zahtjeve za H, C, N, O, S i P, uz daljnje selektivno upravljanje $\mathrm{Na}, \mathrm{K}, \mathrm{Mg}, \mathrm{Ca}, \mathrm{Fe}$, $\mathrm{Mo}$, Se i $\mathrm{Cl}$ za regulaciju energije i prijenos elektrona [3]. Malo je sumnje da je postojalo dovoljno sumporovodika $\mathrm{H}_{2} \mathrm{~S}$ da osigura redukcijsko okruženje potrebno za bitne reakcije s ugljičnim-dioksidom $\mathrm{CO}_{2}$ za sintezu organskih molekula. Uz pomoć mangana kao katalizatora, živi sustavi pronašli su sredstvo za oslobađanje hidrida iz vode. Na kraju su živi organizmi mogli dobiti energiju iz raspada kisika $\left(\mathrm{O}_{2}+\mathrm{C} / \mathrm{H} / \mathrm{N}\right.$ spojevi $\rightarrow \mathrm{N}_{2}+\mathrm{CO}_{2}+$ energija), [3,11]. Slobodni kisik nastao je cijepanjem vode, prvo visokim energetskim zračenjem, a kasnije i fotosintezom. Vjeruje se da je izvorna zemaljska atmosfera bila sastavljena od metana, amonijaka, ugljičnog dioksida, dušika i vodene pare te vodika i helija [12]. Ugljični dioksid je prvo nastao erozijom i razgradnjom minerala. U prisutnosti slobodnog kisika, atmosfera metana i amonijaka je nestabilna, a metan oksidira u vodu i ugljični dioksid. Proizvodnja kisika kroz fotosintezu iznosi otprilike $6,8 \cdot 10^{15}$ mola $^{-1}$, od čega više od $99 \%$ ostaje u atmosferi. Od toga, $90 \%$ je potrebno za oksidacijske reakcije koje prate trošenje i eroziju stijena. Tako ostaje samo $3 \cdot 10^{9}$ mola kisika za obogaćivanje atmosfere [3,5]. Dramatično povećanje stope proizvodnje kisika potječe iz paleozoika, kada je došlo do 
brzog rasta biljnog svijeta, a zatim je uslijedilo odgovarajuće povećanje životinjskog svijeta [10].

Život je počeo u vrućoj vodi, a osobito ga je obilježila bogata raznolikost vrsta algi. Najjednostavniji prokariotski oblici života mogu djelovati i reproducirati se bez prisustva svjetlosti. Zemaljski organizmi postoje na $\mathrm{pH}=1$. Oni stvaraju energiju oksidativnim reakcijama te stoga zahtijevaju sumpor i atmosferski kisik. S druge strane, organizmi koji postoje $\mathrm{u}$ podmorskim toplim izvorima općenito su anaerobni. Osim apsolutnog zahtjeva za vodom, oni također trebaju varijabilne količine $\mathrm{CO}_{2}, \mathrm{H}_{2}, \mathrm{H}_{2} \mathrm{~S}$, $\mathrm{CO}, \mathrm{CH}_{4}$ i SO ${ }_{4}^{2-}$. Kako se zemlja hladila, tako su i evolucijski pritisci doveli do opstanka i daljnjeg razvoja organizama koji su manje podložni toplini. Sve je više dokaza da su kometi sastavljeni prvenstveno od leda te da sadrže i druge strukture povezane s ledom (npr. klatratne hidrate) $[3,5]$.

\section{Dostupnost vode, njena uporaba i kvaliteta}

Održavanje života na Zemlji ovisi o adekvatnoj dostupnosti vode prihvatljive kvalitete, kao i na dobro reguliranoj temperaturi i vlažnosti okoliša. Oceani zadovoljavaju ova oba uvjeta, izravno ili neizravno. Oni imaju snažan utjecaj na kopnenu klimu i na razine oborina. Kao primjer, dati će se jedan stabilizirajući učinak Golfske struje. Ona je $150 \mathrm{~km}$ široka i 0,5 $\mathrm{km}$ duboka te teče maksimalnom brzinom od 2,5 m/s od Meksičkog zaljeva do Arktičkog oceana, sjeverno od Norveške [3]. Pad temperature vode za vrijeme njenog prolaska na sjever je oko $20^{\circ} \mathrm{C}$. Ovaj pad temperature je ekvivalentan prijenosu energije od oko $5 \cdot 10^{13} \mathrm{~kJ} / \mathrm{km}^{3}$, što je jednako toplinskoj energiji koja nastaje izgaranjem 7 milijuna tona ugljena. Gornje iznesene vrijednosti, u kombinaciji s protokom struje, osiguravaju kretanje $100 \mathrm{~km}^{3}$ vode na sat, što je ekvivalentno količini energije koja se dobiva od 175 milijuna tona ugljena. Topla oceanska strujanja tako djeluju kao veliki izmjenjivači topline i odgovorni su za održavanje umjerene klime na većem dijelu zemljine površine [10]. Oceani su sposobni pohraniti velike količine energije zahvaljujući velikom toplinskom kapacitetu vode. Ostala fizikalna svojstva tekućine koja uvelike utječu na naš okoliš je niska gustoća leda u odnosu na gustoću tekućine i fenomen negativnog koeficijenta ekspanzije hladne vode. Ta svojstva su odgovorna za zamrzavanje vodenih masa od površine prema dolje, s očitim implikacijama za opstanak vodenog života.

Osim univerzalne važnosti za održavanje života, voda također ima sve veću ulogu u industriji. Uz opće prepoznavanje nafte kao resursa koji se troši, kao i ekološkog razloga, voda postupno zamjenjuje organska otapala u mnogim kemijskim procesima. Većina oborinske vode vraća se izravno u oceane, dok ostatak pada na kopno kao rezultat jednog od tri procesa koji uključuju oborine iz toplog vlažnog zraka: a) ciklon - topla zračna masa 
(stacionarna ili u horizontalnom kretanju, susreće se s hladnom zračnom masom), b) konvektivno - zračna masa koja prima toplinu i vodenu paru i koja se hladi dok se diže vertikalno te c) u planinskim područjima pokretna topla zračna masa je prisiljena podizati se te izgubiti toplinu kada naiđe na planinsku barijeru. Kako se zračna masa spušta niz zavjetrinsku stranu, ponovno se zagrijava, a oborine se smanjuju, što rezultira „kišnim sjenilom", koje u ekstremnim slučajevima može dovesti do pustinjskih područja [2,3]. Oko $30 \%$ vode koja se ne vraća izravno u atmosferu isparavanjem zove se otjecanje i predstavlja potencijalno dostupnu opskrbu vodom u regiji. Dio otjecanja se na kraju skuplja u površinskim vodotocima, ali veći udio prodire u podzemlje kroz propusno tlo. Takva podzemna voda se može pojaviti na površini u arteškim izvorima ili povremenim izvorima u obliku estavela ili u obliku vrulja ispod razine mora. Potoci i rijeke ulaze u oceane koji na kraju dobivaju preko $90 \%$ ukupnog otjecanja. Posljednjih godina znanost o hidrologiji podzemnih voda značajno je napredovala zbog opsežnog prikupljanja hidroloških podataka i eksplozije istraživanja u botanici, kemiji, fizici i meteorologiji. Podzemni tok vode procjenjuje se na 33-40 \% prosječnog ukupnog otjecanja, iako je taj prosjek u nekim područjima na planeti znatno veći [3]. Prema provedenim analizama opskrbe vodom, procjenjuje se da oko $80 \%$ postojećih zaliha još uvijek dolazi iz površinskih izvora. Primjera radi, pet država u SAD-u (Arkansas, Arizona, Mississippi, Novi Meksiko i Južna Dakota) ovise o podzemnim vodama za više od polovice svojih ukupnih zaliha vode. Osam drugih država, među kojima su Kalifornija i Teksas, koriste podzemne vode za $25-50 \%$ svojih potreba. Iznenađujuće, neke regije (kao što je provincija Ontario u Kanadi), koje su bogate jezerima i rijekama, za potrebe vodom $\mathrm{u}$ industriji i domaćinstvu koriste isključivo sirovu vodu iz akumulacija podzemnih voda [3]. To dovodi do ozbiljnih problema tijekom razdoblja naglog porasta populacijske i industrijske aktivnosti. Podzemne vode od presudne su važnosti u polusuhim zemljama gdje veliki dio stanovništva ovisi o poljoprivredi. Tako se u Indiji više od $90 \%$ ukupne potrošnje vode odnosi na navodnjavanje. Kiša je izrazito sezonska i neujednačena, a uspješna poljoprivreda je nemoguća bez opsežnog navodnjavanja. Područje navodnjavanja gotovo se udvostručilo od početka planiranja vodnih resursa prije otprilike 60 godina, ali čak i sada iznosi samo 30\% bruto obrađene površine $[1,3]$. Podzemne vode ukupnom navodnjavanju doprinose $40 \%$. Dok su oborine glavni izvor podzemnih voda, infiltracija i skladištenje vode ovisi uglavnom o geološkim formacijama. Glavne nekonsolidirane (porozne) formacije odgovaraju aluvijalnim ravnicama izgrađenim od velikih riječnih sustava Inda, Gangesa i Brahmaputre. Ta su područja također relativno bogata kišama. Oni čine 30\% ukupne površine zemljišta, ali sadrže 50-60\% korisnih resursa podzemnih voda [3]. Gotovo dvije trećine kopnene mase sastoje se od tvrdih formacija stijena koje 
ne sadrže pore i drže samo ograničene količine vode u zonama rasjeda. Svega 5\% kopnene mase sastoji se od polukonsolidiranih formacija, od kojih je većina na sjeverozapadu (sušna regija s malo kiše). Podzemne vode su neujednačene kvalitete i djelomično mineralizirane. U toj je regiji otkriveno formiranje pješčenjaka u kojoj se nalazi 7000-godišnji rezervoar vode koji iznosi oko $25 \mathrm{~km}^{3}$ (bez mogućnosti punjenja). Slični tipovi velikih podzemnih spremnika također su se nalazili u drugim pustinjskim područjima, npr. poluotoku Sinaj i Libyi [1,3]. Veći dio razvoja podzemnih voda u Indiji odvija se kroz jednostavne bušotine različitih tipova koje su dovoljno jeftine za poljoprivrednike na individualnoj osnovi. Usputno je pokrenut poseban javni razvojni program za bolje korištenje potencijala za navodnjavanje, kao i poseban program istraživanja za kontinuirano praćenje razine vode i promjena u kvaliteti vode.

Održavanje i kvaliteta akumulacija podzemnih voda također se odnosi na praksu korištenja zemljišta i tretmana. Razvijene zemlje pokazuju da polusuhi uvjeti ne moraju biti prepreka poljoprivrednoj eksploataciji. Zemlja i klima suhe i polusušne Australije usporedive su s onima $u$ Aziji i Africi, ali su socioekonomski čimbenici vrlo različiti. Proteklih 140 godina se dio vode koja se može piti u suhoj i polusušnoj Australiji koristi za ispašu ovaca i goveda. Razvoj povezane industrije vune i mesa bio je postupak pokušaja i pogrešaka s pretjerano optimističnim procjenama produktivnosti i otpornosti prirodnih resursa. Sadašnja razina iskorištavanja i dalje je diskutabilna, ali je u posljednjih 60 godina provedeno integrirano istraživanje s dugoročnim pozitivnim ciljevima [3]. Komplicirane međusobne veze između meteorologije, geologije i poljoprivrede također se istražuju tehnikama računalnog modeliranja, iako je razumijevanje sustava u pogledu dispozicije potencijalnih zaliha sirove vode, njene vremenske varijabilnosti i potrebe za usjevom još nepotpuno. Mnogi statistički i eksperimentalni modeli, s vremenskim varijablama kao inputima, razvijeni su i koriste se na terenu.

Međunarodni institut za upravljanje vodama (The International Water Management Institute, IWMI) sa sjedištem u Šri Lanki pokrenuo je veliki program za poboljšanje i usmjeravanje politika navodnjavanja, posebno u svijetu u razvoju. Tijekom proteklih 50-tak godina povećanje proizvodnje hrane postignuto je širenjem navodnjavanih površina i povećanjem prinosa usjeva po jedinici potrebe za vodom, uglavnom razvojem novih sorti. Opseg povećanja potrošnje i potražnje vode najbolje ilustriraju sljedeće brojke: od 40000 brana samo je njih 5000 izgrađeno nakon 1950. godine. Istovremeno se povećala eksploatacija podzemnih voda u mnogim područjima planete Zemlje [1,3]. U pojedinim polusušnim dijelovima Kine i Indije (područjima s velikom svjetskom proizvodnjom pšenice) razine voda padaju za 1-3 m godišnje. Prekoračenje količina podzemnih voda trenutno skriva ozbiljnost buduće nestašice voda. U nastojanju da 
pomogne Vladama, IWMI institut je proizveo vjerojatno najrealniji model u naporima za procjenu različitih scenarija opskrbe vodom i potražnje za 2025. godinu. S obzirom na procjenu za 45 zemalja koje predstavljaju $83 \%$ svjetske populacije, stvara se relativno optimistična mogućnost tih zemalja da postignu povećanje proizvodnje hrane [3]. Model IWMI-a predviđa da će 2,7 milijardi ljudi, uključujući znatan broj onih koji žive u Indiji i Kini, živjeti u regijama s ozbiljnim nestašicama vode. Nestašice vode također mogu dovesti do sukoba na Bliskom istoku i podsaharskoj Africi, gdje siromašno stanovništvo već ekstremno oskudijeva s vodom. Međutim, također će biti pogođena i druga, bogatija područja budući da postoje sve veći trenutni zahtjevi potrošnje vode nekih veliki svjetskih rijeka, npr. Nila, Žute rijeke (Hoangho), Colorada i Rio Grandea [3,11].

Najznačajnija je situacija u Aziji, gdje se navodnjavana površina gotovo udvostručila u razdoblju od 1965. do 1995., uz odgovarajuće povećanje površine obradivog zemljišta od samo $10 \%$. U Europi je površina obradivog zemljišta u tom razdoblju zapravo pala, iako je navodnjavanje povećano za $30 \%$. Ekonomija svjetske proizvodnje hrane stalno se mijenja. Danas $5 \%$ svjetskih poljoprivrednika proizvodi polovicu svjetske hrane [3]. Nekim zemljama, umjesto da se uključe u velike inženjerske projekte namijenjene povećanju zaliha vode, ekonomičnijim će se učiniti uvoz žitarica. Ova praksa nazvana je „trgovina virtualnom vodom“. Tako je sredinom 1990-ih oko 100 milijuna tona izvoza pšenice odgovaralo godišnjoj "trgovini vodom“ od najmanje $100 \mathrm{~km}^{3}$. Na Dalekom istoku, 50\% ukupnog usjeva uzgaja se bez navodnjavanja, uglavnom u područjima velikih riječnih delta (primjer Vijetnama kao drugog najvećeg izvoznika riže na svijetu).

Godine 1971. Nacionalna zaklada za znanost SAD-a naručila je studiju kako bi istražila izvedivost primjene koncepta procjene tehnologije na planirane projekte modifikacije vremena (tzv. klimatska modifikacija). Ova je studija utemeljena na prijedlogu povećanja protoka rijeke Colorado zbog formiranja oblaka u gornjem slivu rijeke Colorado tijekom zime, čime se povećava nakupljanje snijega u planinama. Neki od važnijih čimbenika koji su uzeti u cjelokupnu procjenu bili su: trošak (učinkovitost) povećanja nakupine snijega, temeljen na tadašnjem tehničkom znanju i dostignuću, procjena poboljšanja u omjeru troškova i koristi u sljedećih pet godina, ekološki utjecaj na područje, stavovi javnosti o projektu, pravne posljedice i potencijalne promjene u javnoj politici te usporedba povećanja nakupine snijega u pogledu drugih vodnih resursa na danom području i izvan njega [3]. Nalazi studije objavljeni su 1974. godine i jasno su ukazali na uzajamno djelovanje tehničkih, ekonomskih, socioloških i pravnih čimbenika koje je potrebno uzeti u obzir pri donošenju odluka. Tehnički, metoda zasijavanja oblaka snijega srebrnim jodidom osigurala bi jeftin način povećanja zaliha vode. U usporedbi s čistim snijegom, što je ekvivalentno $17,5 \mathrm{~km}^{3}$, dodatnih $4,4 \mathrm{~km}^{3}$ moglo bi se proizvesti po cijeni koja je vrlo povoljna u usporedbi s 
većinom drugih vodnih zaliha $[3,12]$. Navedena metoda bi povećala količinu snijega na visinama iznad $2500 \mathrm{~m}$ za $20-25 \%$. Ekološki, ekonomski i socijalni utjecaj vjerojatno bi bio negativan, ali umjeren. Posljedice na okoliš bi uključivale povećanu opasnost od lavina i poplava. Povećano otjecanje otopljene vode dovelo bi do veće količine sedimenta, viših razina otopljenih soli i nižih srednjih temperatura vode tijekom proljeća. To bi zauzvrat utjecalo na faunu kroz njihove učinke na uzgojne navike i životne cikluse. Također, trebalo je razmotriti povećanu mogućnost štetočina i epidemija zbog upotrebe srebrenog jodida koji se koristi za zasijavanje oblaka, a koji bi rezultirao prilično teškim naslagama u blizini mjesta proizvodnje. Studija nije uzela u obzir mogući učinak koji bi program za poboljšanje snijega mogao imati na regije istočno od ciljnog područja, npr. mogu li te regije koje su već u kišnoj sjeni Stjenjaka (planine Rocky Mountain) pretrpjeti daljnje smanjenje količine oborina. Istraživanje uključene populacije pokazalo je nepovjerenje prema saveznim agencijama i prvenstveno na činjenicu da je ometanje prirodnih vremenskih prilika nemoralno i neodrživo. Bez obzira na društvena i institucionalna pitanja, prilično je jasno da smo tehnološki i ekonomski odavno u mogućnosti osigurati adekvatne zalihe vode, čak i u uvjetima povećanih zahtjeva.

\section{Utjecaj čovjeka na vodne resurse}

U razvijenom svijetu, ljudska zabrinutost često je vezana uz kvalitetu pitke vode i poboljšanje regionalne vodoopskrbe. Treba spomenuti važne standarde kvalitete vode koje se primjenjuju u medicini i industriji, poljoprivredi, svakodnevnom životu i rekreaciji. U razvijenim zemljama visoki standard čistoće pitke vode uzima se „zdravo za gotovo“. Globalna analiza provedena 2000. godine ukazala je na činjenicu da oko 2,9 milijardi ljudi (66\% stanovništva u zemljama u razvoju) nemaju pristup toaletu pa čak niti pristojnu septičku jamu $[3,10]$. Općenito, u opskrbi pitkom vodom postignut je napredak. Od 1990. do 1995. godine, udio ljudi u zemljama u razvoju s pristupom sigurnoj pitkoj vodi porastao je sa 61 na 75\%. Gradske sirotinjske četvrti predstavljaju najgoru noćnu moru, gdje zagađena voda uzrokuje mnoge smrti, posebice djece. Tamo gdje postoji nedovoljna opskrba sigurnom pitkom vodom, stanovništvo se potiče da prokuhava vodu, ali mjesečni trošak potrebnog goriva za zagrijavanje te vode može iznositi trećinu mjesečnog dohotka obitelji, čineći taj proces vrlo teškim izborom. Najimpresivniji napredak u promicanju projekata sanitarne zaštite vode u zajednici napravili su socijalističke zemlje, posebno Kuba i Kina. Obrazovanje ljudi je odigralo glavnu ulogu u postizanju poboljšanja. Mnogi ekonomisti vjeruju da bi se životi spasili, a zdravlje poboljšalo nudeći kredit siromašnim ljudima kako bi im pomogli da započnu posao i 
generiraju nešto novca. To bi im, zauzvrat, omogućilo izgradnju pokrivenih bušotina i uvođenje određenih sanitarnih poboljšanja (količinu i kvalitetu vode za osobnu higijenu).

U borbu protiv industrijskog onečišćenja okoliša uključen je sve veći broj aktivista i posebne interesne skupine ljudi diljem svijeta. Društvo u bogatim zemljama također je postalo svjesno opasnosti koje prate gospodarski rast. Napisano je mnogo knjiga o tzv. „bruto nacionalnom nusproduktu" unutar kojih se razmatraju posljedice antropogenog utjecaja na promjene u kvaliteti vode i utjecaju promjene zdravstvene, poljoprivredne i industrijske prakse. U osnovi, postoje dvije vrste kemijskog onečišćenja vodenog okoliša, bilo da se radi o rijeci, oceanu ili podzemno akumuliranoj vodi. Organoklorni pesticidi su primjeri jedne klase onečišćujućih tvari koji se pojavljuju kada tehnološki napredak proizvodi novi materijal koji ne postoji u prirodi. Ako je takva tvar kemijski stabilna u okolišu ili je samo djelomično degradirana u drugi stabilan oblik, situacija se dodatno komplicira [7]. Industrijske otpadne vode još uvijek se ispuštaju u ogromnim razmjerima (npr. za svaku tonu papira proizvede se 250 tona otpadne vode). Iako se otpadne vode pročišćavaju prije ispuštanja $\mathrm{u}$ recipijent, mnogi industrijski procesi uzrokuju toksične materijale u velikim koncentracijama koje je teško potpuno ukloniti (npr. razina teških metala u morskoj sredini). Učinci trajnih industrijskih kemikalija na vodeni svijet mogu biti posebno ozbiljni zbog niske topljivosti mnogih organskih spojeva koji se nalaze u otpadnim vodama. Ti spojevi formiraju tanki sloj na površini vode, debljine svega jedne molekule, a njihova prisutnost drastično modificira površinsku napetost i brzinu kojom voda preuzima kisik $[3,7]$.

Drugi tip zagađenja uzrokovan je tvarima koje služe kao hranjive tvari $\mathrm{u}$ biosferi, tj. one postoje u prirodi i mogu se metabolizirati od strane živih organizama. Takve tvari, iako su neophodne za održavanje života, predstavljaju probleme kada njihove koncentracije u određenom okruženju prelaze kritične vrijednosti. One tada mogu poremetiti biološku ravnotežu, npr. međusobne interakcije populacija različitih biljaka i životinja. Jedan takav primjer se dogodio u jezeru Erie (SAD) tijekom 1950-ih i 1960-ih godina kada je nastao ekološki poremećaj zbog uvođenja velikih količina hranjivih tvari za biljke. Takve tvari u visokim koncentracijama uzrokuju prekomjerni rast jezerskog raka, što u ekstremnim slučajevima dovodi do kolapsa ekosustava te uključivanje anorganskih i organskih štetnih spojeva (posebno spojeva koji sadrže dušik (amonijak, nitriti i nitrati) i fosfor). Nedostatak dušika ili fosfora može ograničiti rast biljaka, a njihova opskrba regulirana je primjenom gnojiva za poticanje razvoja biljke. Međutim, taj isti postupak može biti štetan u vodenoj sredini.

Ljudskim razvojem može doći do značajnog narušenja u ekološkom ciklusu zbog povećanja stope prirasta i količine različitih uključenih 
invazivnih vrsta. Tako je u posljednjih 90 godina ispuštanje hranjivih tvari u jezero Erie (SAD) uzrokovalo da proces eutrofikacije napreduje do točke koja se prirodno ne bi dogodila 20000 godina. U godinama između 1942. do 1967. raspoloživi sadržaj dušika (amonijaka ili nitrata) povećao se za $50 \%$, a sadržaj topivog fosfora za nevjerojatnih 500\% [3]. Slični problemi nastaju tamo gdje jezera postaju „industrijalizirana“, bilo da se radi o prerađivačkoj industriji, poljoprivredi ili domaćem razvoju (npr. Bajkalsko jezero i Kaspijsko more u Rusiji, te jezero Tiberijada u Izraelu). Deterdženti su najveći pojedinačni izvori fosfata koji je koncentriran u kanalizaciji urbanih područja. Najveći problemi životinjskog otpada nastaju kod velike koncentracije stoke i peradi u manjim i gusto naseljenim područjima. Vrlo visoke razine nitrata u opskrbi pitkom vodom mogu dovesti do patološkog stanja poznatog kao methemoglobinemija (hematološki poremećaj kod kojega je hemoglobin u oksidiranom obliku i ne može vezati kisik), učinaka koji su slični trovanju ugljičnim monoksidom [3,7].

Postoji još jedan proces koji se može razmatrati pod općim naslovom onečišćenja: salinizacija ili zaslanjenje podzemnih voda prirodnim ili umjetnim putem. Problemi koji proizlaze iz rasprostranjene prirode slanih tala mogu biti dodatno otežani geografskom rasprostranjenošću populacija i poljoprivrednom praksom koja je uvelike uspjela povećati zaslanjenje tla u sušnim i polusušnim zemljama. Procjenjuje se da zaslanjenje zahvaća najmanje 4 milijuna $\mathrm{km}^{2}$ kopnene površine Zemlje, isključujući područja velikih pustinja $[1,3]$. Vjerojatno su posljedice sekundarnog zaslanjenja još ozbiljnije jer predstavljaju gubitak nekada produktivnog poljoprivrednog zemljišta. Primjera radi, u područjima kao što je Punjab u Indiji, 25\% od $51000 \mathrm{~km}^{2}$ poljoprivrednog zemljišta već je 1960. godine bilo ozbiljno pogođeno zaslanjenjem (oko 10\% izgubljenog područja za poljoprivredu). Zemljište za poljoprivredu se godišnje smanjivalo za $400 \mathrm{~km}^{2}$, a posljedica toga je bila loša kvaliteta vode za navodnjavanje kod koje je uslijed evapotranspiracije došlo do povećanja koncentracije soli u zemljištu [3].

\section{Potrebna kvaliteta vode i metode kondicioniranja}

Kvaliteta pitke vode u velikoj mjeri ovisi o toksikološkim i mikrobiološkim kriterijima koja su utvrdila nacionalna ili međunarodna regulatorna tijela. Prihvaćene metode uvelike ovise o kvaliteti lokalnih podzemnih i/ili površinskih vodnih resursa. Postupno uspostavljanje europskih direktiva, zajedno s privatizacijom poduzeća za vodoopskrbu, potaknulo je ulaganja usmjerena na poboljšanje kvalitete pitke vode. Primarni cilj bilo je smanjenje olova s 50 na $10 \mathrm{\mu gl}^{-1}$ te dozvoljene koncentracije nitrata u vodi na manje od $50 \mu \mathrm{gl}^{-1}$. Moguću mikrobiološku opasnost predstavlja kriptosporidijum (lat. Cryptospiridium) koji se uklanja iz vode za piće procesom filtriranja. 
Sprječavanje mikrobiološke opasnosti postiže se kombinacijom tretmana ozonom, adsorpcijom ugljena, filtracijom i dodavanjem fosfata i koagulanata $[3,7]$. U Nizozemskoj se primjenjuje „prirodna“ filtracija crpljenjem vode kroz pješčane dine. Nijedna metoda nije potpuno sigurna, o čemu svjedoči izrazito publicistička katastrofa u Cornwallu, gdje se 6. srpnja 1988. pojavila visoka koncentracija aluminija u vodi za piće koja može uzrokovati implikacije Alzheimerove bolesti [7].

Tretman izrazito čiste vode, kako to zahtijeva industrija poluvodiča, mora se ocjenjivati prema mnogo strožim kriterijima. Kvaliteta vode se pritom izražava u jedinicama fizikalnih veličina kao što su električna provodljivost ili otpornost $\left(\mu \mathrm{S} \mathrm{cm}^{-1}\right)$, ukupna otopljena tvar $\left(\mathrm{mg} \mathrm{l}^{-1}\right), \mathrm{pH}$ faktor i slično. Godine 1894. Kohlrausch je odredio ono što je kasnije postalo poznato kao „provodljivost vode“ $\left(0,055 \mu \mathrm{cm}^{-1}\right.$ pri $\left.25^{\circ} \mathrm{C}\right)$, nizom od 26 destilacija u kvarcu [10]. Rezultati su bili prihvaćanje provodljivosti kao valjane mjere čistoće, zajedno s pogrešnim zaključkom da se provodljivost može prihvatiti kao dokaz odsutnosti svih otopljenih ili suspendiranih nečistoća. Voda s niskom provodljivošću (pripremljena ionskom izmjenom) ipak može imati smanjenu površinsku napetost, što ukazuje na prisutnost znatnih koncentracija apsorbiranih površinski aktivnih tvari neionske prirode. Ovisno o podrijetlu sirove vode, takvi kontaminanti se mogu sastojati od produkata razgradnje humusne i/ili folne kiseline.

Rasprava o kvaliteti može biti korisna polazna točka za klasifikaciju prirodne vode. Najčešći primjer je podjela na "meke“ i "tvrde“ vode. Tvrdoća se obično izražava u koncentracijama kalcija i magnezija koje pokrivaju raspon od 60-180 ppm. Priroda aniona određuje može li se tvrdoća ukloniti ključanjem (privremena tvrdoća, npr. karbonati i bikarbonati) ili je tvrdoća trajna (npr. sulfati i kloridi), [12]. Voda iz mnogih prirodnih bunara koja sadrži velike količine otopljenih minerala i plinova se smatra „zdravom“ pa čak i „zdravstveno ispravnom“ kada se prodaje u bocama. Takva „prirodna“ voda je, zbog potrebe za visoko kvalitetnom vodom, neprihvatljiva za potrebe u medicini i industriji. U stvarnom izboru metoda kondicioniranja mora se uzeti u obzir kakvoća sirove vode, a osobito koncentracije otopljenih i/ili suspendiranih tvari $[3,12]$. Uobičajeni industrijski procesi kondicioniranja sirove vode uključuju procese filtracije, destilacije, ionsku izmjenu, reverznu osmozu, elektrodijalizu i izlaganje UV zračenju. Skladištenje kondicionirane vode može predstavljati probleme u pojedinim industrijama. Najveći prioritet se mora dati isključivanju atmosferske kontaminacije jer će čestice koje se prenose zrakom brzo smanjiti kvalitetu vode. Ostali čimbenici koji zahtijevaju pažnju uključuju kontinuirano kretanje vode u spremniku (cirkulaciju), hidraulički proračun spremnika, konstrukcije i pomoćnih uređaja, te postupke čišćenja.

Proizvođači lijekova, bolnice i druge medicinske ustanove zahtijevaju vodu različitih stupnjeva kvalitete. Najstroži kriteriji primjenjuju se na 
ocjenu „voda za injekcije“. Potrebe za visokokvalitetnom vodom u medicini potječe još od 1656. godine kada je sir Christopher Wren, uz pomoć Roberta Boylea, pokušao intravenozno ubrizgavanje lijeka životinji pomoću šupljega pera. Hipodermička injekcija analgetskih tekućina u ljude potječe iz 1855. godine, a parenteralno davanje lijekova sada je uobičajena klinička tehnika [3]. Voda je glavno sredstvo za većinu pripravaka, a zahtjevi čistoće za vodene otopine uključuju kompatibilnost s krvlju, učinkovitu topljivost krutih komponenata, fizičku, kemijsku i mikrobiološku stabilnost, odsustvo toksičnih supstanci, sprječavanje preosjetljivosti i iritiranje te da ne mijenjaju pH vrijednost. Dopuštene metode pripreme vode za injekcije sada su strogo regulirane te su uglavnom ograničene na destilaciju ili reverznu osmozu. Nakon toga slijedi autoklaviranje (postupak sterilizacije na $121^{\circ} \mathrm{C}$ uz primjenu tlaka od $103421 \mathrm{~Pa}$; provodi se tijekom 15 do 40 minuta u autoklavu; primjena u stomatologiji i u proizvodnji betona), [3]. Elektronska industrija zahtijeva ultra čistu vodu za čišćenje površina aktivnih kristala, uklanjanjem iona alkalija i teških metala.

\section{Ekonomika potrošnje vode}

Nacionalni i globalni prosjeci o potrošnji i opskrbi vodom predstavljaju krivu sliku jer regionalne fluktuacije u odnosu na srednje vrijednosti mogu biti prilično velike. Prosječna dnevna potrošnja vode po osobi u Europi kreće se prema UNESCO-voj računici između 300 i 600 litara (u RH je prosjek oko 127 l/dan prema izvješću EUROSTAT-a iz 2013. g.) [4]. Prosjek potrošnje vode u carskom Rimu iznosio je dnevno oko $230 \mathrm{l} /$ osobi [3]. Ta količina je vjerojatno pala tijekom Srednjeg vijeka i ponovno se povećala tijekom posljednja dva ili tri stoljeća. Ono što se promijenilo od 2000. godine je ukupna populacija na zemlji i rast industrije koja troši vodu. Korištenje vode jedne nacije, koja je pokazatelj njezina industrijskog razvoja, obično raste za 2-3\% godišnje. To otvara pitanje potencijalne nestašice vode u budućnosti. Desalinizacija morske vode, sada tehnički izvediva, mogla bi zauvijek voditi brigu o ljudskim potrebama. Međutim, cijena vode proizvedene iz mora još je uvijek mnogo veća od one koja se dobiva iz drugih izvora. Nasuprot tome, isparavanje svježe vode može se spriječiti širenjem slojeva supstanci debljine jedne molekule, kao što je cetilni alkohol (emulgator u kozmetici), na površini vode, uz znatno niže troškove od destilacije $[3,11]$. No, i ovaj postupak košta mnogo više od proizvodnje slatke vode. Iskorištavanje raspoloživih resursa postat će skuplje jer će se zahtjevi u budućnosti povećavati zbog potreba većih količina pitke vode.

Voda kao ekonomsko dobro ili resurs pokazuje bitne kvalitete svih drugih ekonomskih dobara ili resursa. Kao i proizvodnja drugih 
ekonomskih dobara, proizvodnja vode mora konačno biti u skladu sa zakonom smanjenih prinosa. Društvo, ako to želi, može razviti dodatne zalihe vode, ali samo po višoj jediničnoj cijeni. Današnji stručnjaci, čija je odgovornost pružanje ili raspodjela zaliha vode, ne shvaćaju blisku povezanost vode i drugih dobara zato što smatraju da vode „ima“ u obilnim količinama. Ta su opažanja vjerojatno potaknula Adam Smithovu razliku između „vrijednosti u upotrebi“ i „vrijednosti u zamjenu“, izražene u njegovom „paradoksu dijamantne vode“ [3]. On je pretpostavljao da dijamanti imaju tržišnu vrijednost, ali nemaju vrijednost u uporabi, a voda ima visoku vrijednost u uporabi, ali ne i vrijednost na tržištu. Ljudi su u velikoj mjeri odgovorni za globalni problem nestašice vode jer su donijeli zakone u kojima se voda promatra odvojeno od drugih ekonomskih dobara, odnosno zakone koji imaju malo utjecaja na uvjete za optimalnu raspodjelu vodnih resursa. Pojedini zakoni o vodama na nacionalnoj razini i uobičajena praksa prodaje vode na osnovi paušalne naknade teško da su u skladu s održivim razvojem na promatranom području.

Dio oborina iz godine u godinu bi trebao biti predvidljiv kako bi se uspostavili pouzdani prediktori. Poljoprivrednici za život i individualni razvoj teško mogu odgovoriti na prognoze sezonskog karaktera jer njihove poljoprivredne metode i stavovi nisu dovoljno fleksibilni. Ako se predvidi posebno sušna sezona, hrana se može uskladištiti, a goveda se mogu ograničiti kontroliranjem pristupa bušotinama. Također, mogu se osigurati financijska sredstva za migracije ljudi s područja s najvećim ugroženim rizikom. Vlade pojedinih zemalja bi mogle razviti određenu neovisnost od klimatskih fluktuacija koordiniranjem gospodarskih i drugih razmjena s drugim klimatskim područjima. Budući da se oborine brzo mijenjaju s udaljenošću u tropskim predjelima, sezonski sušna i vlažna područja se često nalaze u blizini. Prije podijele Zapadne Afrike između kolonijalnih sila, vlažne i suhe regije tradicionalno su bile povezane uzajamnim trgovinskim sustavima. Novija nacionalna struktura Zapadne Afrike rezultirala je političkim preprekama na tim prirodnim vezama sjever-jug, čime su sjeverne zemlje „izolirane“ njihovim nepouzdanim oborinama. Iako politički neovisne, one ne mogu postići poljoprivrednu samodostatnost na određenoj najsiromašnijoj razini, niti se mogu samostalno nositi $\mathrm{s}$ posljedicama svojih nepravilnih klimatskih uvjeta.

Najvažnije razlike u iskorištavanju sušnih i polusušnih područja u Americi ili Australiji u usporedbi sa zemljama u razvoju smatraju se socijalnim, ekonomskim i političkim. Australski stočar vodi visoko kapitaliziranu i mehaniziranu tvrtku, dobro integriranu s područjima $\mathrm{s}$ većom količinom oborina kroz komunikacijski, distribucijski i tržišni sustav. Uspjeh i neuspjeh izračunavaju se u smislu dobiti. To je potpuno drugačije od industrije za opstanak u mnogim drugim sušnim područjima, gdje jedna godina suše može značiti glad ili smrt. Tehnički gledano, ne 
postoje veliki problemi u prilagodbi uspješnih praksi upravljanja vodom prema zemljama Trećeg svijeta, jer su fizička ograničenja raspodjele vodnih resursa vrlo slična. Glavne prepreke u provedbi u tim zemljama su gospodarske, socijalne i, prije svega, političke prirode. Problemi vezani uz postizanje uravnoteženog sustava upravljanja vodama neće biti prevladani samo interdisciplinarnim istraživanjima, već informacije dobivene međunarodnim istraživačkim aktivnostima moraju dovesti do lokalnih ekonomskih i društvenih promjena kroz prosvijećeno ponašanje u zajednici i hrabro političko vodstvo.

\section{Umjesto zaključka}

Voda je nezamjenljivo prirodno bogatstvo bez koje život čovjeka i svih ostalih oblika života na Zemlji ne bi mogao opstati. U tijelu novorođenčeta starog tri dana ima oko $97 \%$ vode, a u tijelu odraslog čovjeka 70 do $80 \%$ [3]. Za osnovne fiziološke potrebe čovjek troši oko 2-3 l/dan, odnosno proizlazi da se dnevno u svijetu samo za osnovne potrebe stanovništva troši oko 10$15 \mathrm{~km}^{3}$ slatke vode. Prema standardima Svjetske zdravstvene organizacije, za sanitarne potrebe stanovništva potrebno je prosječno oko $150 \mathrm{l} / \mathrm{stan}$./ dan, odnosno oko $750 \mathrm{~km}^{3}$ vode. Atmosferska voda je uglavnom zagađena neorganskim tvarima (pijeskom, prašinom i raznim plinovima). Zagađena voda uzrokuje mnoge infektivne bolesti poput trbušnog tifusa, paratifusa A i B, dizenterije, kolere, poliomijelitisa, zarazne žutice, kuge itd. Od svih prirodnih dobara, voda je postala najdragocjenija te, planetarno gledano, ona predstavlja „krvotok“ Zemlje. Njena današnja svjetska potrošnja dostiže oko $3500 \mathrm{~km}^{3}$ godišnje ili oko $800 \mathrm{~km}^{3}$ po svakom stanovniku planete $[3,4,6]$.

Procjenjuje se da oko $40000 \mathrm{~km}^{3}$ slatke vode svake godine istječe iz rijeka i jezera, dok dvije trećine te količine nestaje u poplavama ili ulazi u močvare i tlo prije nego bismo je mogli prikupiti ili pohraniti. Voda u tekućem stanju prekriva $71 \%$ površine našeg planeta, pri čemu je odnos volumena vode prema volumenu Zemlje 1:777 [3,4]. Voda u biosferi ima značajnu ulogu kao stanište za veliki broj organizama, važan je činilac u reakcijama fotosinteze, predstavlja otapalo za sve hranjive elemente tla, hrana je za većinu živih organizama, važan je prenositelj energije u svom biogeokemijskom ciklusu te je ujedno i značajan klimatološki činilac u toplinskoj bilanci Zemlje. U dogledno vrijeme bi se zbog utjecaja globalnog zatopljenja Zemlja u narednih 100 godina mogla zagrijati za $2,5^{\circ} \mathrm{C}$ zahvaljujući prisutnosti sve više stakleničkih plinova u atmosferi (osobito $\mathrm{CO}_{2}$ ), [3]. To bi moglo uzrokovati porast razine mora za 40 -tak $\mathrm{cm}$ zbog zagrijavanja i širenja vode te otapanja polarnog leda u more. Niski otoci i 
priobalna područja mogli bi biti trajno poplavljeni, uz posljedice gubitaka više od milijun domova i velikih zaliha pitke vode.

Stotine milijuna ljudi u zemljama u razvoju nemaju pitku vodu ni zadovoljavajuće higijenske uvjete. Nezdrava voda glavni je svjetski uzročnik bolesti. Ljudi koji piju, kuhaju, peru i kupaju se u zagađenoj vodi obolijevaju od malarije, riječnog sljepila, kolere, gube, žutice, žute groznice, a prijenosnici su i drugih teških zaraza. Od tih bolesti godišnje u svijetu umire najmanje 25 milijuna ljudi, od toga 15 milijuna djece $[3,4]$. Tehnički progres i daljnji razvoj naše civilizacije nezamisliv je bez zaštite vodenih bogatstava i njihovog pažljivog korištenja. Povećana urbanizacija, gospodarski i opći razvoj življenja neminovno dovode do stalnog porasta potreba za vodom, čime se ugrožavaju vodni resursi i općenito okoliš. Time voda postaje ograničujući čimbenik potrebnog općeg razvoja i održivosti prirodnih ekosustava. U tom pogledu potrebno je poštivati temeljna načela koja definiraju vodu kao jedinstveno prirodno bogatstvo, načelo da bez vode, zraka i hrane nema života te da voda kao čimbenik proizvodnje mnogih gospodarskih djelatnosti nema samo ekonomsku i političku već i moralnu vrijednost.

Hrvatska spada u zemlje relativno bogate vodom. Obiluje površinskim tekućim i stajaćim vodama te podzemnim vodama. Prema UNESCO-u, ona je po bogatstvu voda na 5. mjestu u Europi, odnosno 42. u svijetu [4]. Zbog znatnijih prostornih i vremenskih varijacija godišnjih oborina dolazi do nejednake prostorne raspodjele voda u Hrvatskoj. Podzemne vode u RH su vrlo važan segment hrvatskoga vodnog bogatstva, a koriste se u javnoj i privatnoj vodoopskrbi, navodnjavanju, industriji te postaju i komercijalno zanimljiva "roba“ kao izvozna sirovina. Prema podacima za 2006. godinu, u RH je ukupno isporučeno $401 \cdot 10^{6} \mathrm{~m}^{3}$ vode $\left(226 \cdot 10^{6} \mathrm{~m}^{3}\right.$ za potrebe gospodarstva i $175 \cdot 10^{6} \mathrm{~m}^{3}$ za kućanstvo) [4].

Suvremena industrija, uključujući i visokotehnološka poljoprivredna rješenja u kojima se upotrebljavaju velike količine umjetnih gnojiva i pesticida, zatrovala je rijeke i mora, tla i usjeve te ljudske i životinjske prehrambene lance kemikalijama koje se prirodno ne mogu razgraditi, niti nestati. Progresivnim razvojem znanosti i tehnologije zaboravili smo kako je „mudro" ne miješati se u posao prirode te smo uveli nerazumnu praksu življenja nad kojom nemamo potpun nadzor i čije posljedice su danas jasno vidljive. Zatrovali smo zrak u mnogim gradovima, a mnoga jezera i rijeke su u biološkom smislu „polumrtva“. Biosfera na planeti Zemlji je izgubila sposobnost samopročišćavanja i sve se teže nosi s vlastitim snagama kako bi izašla na kraj s teretom koji je čovjek izbacio u nju.

Mnoge su stvari izvan ljudskog nadzora, iako svijet koji će budući naraštaji od nas naslijediti uvelike ovisi o našim današnjim odabirima, i kao pojedinaca i kao članova svjetske zajednice. Čovječanstvo mora biti razumno i treba naučiti cijeniti, poštivati i skrbiti za planet na kojem i s 
kojim živi. Obrazovanje u pogledu očuvanja okoline i održivog razvoja je ključ napretka. Zakonom o vodama RH (NN, br. 56/13) jasno je definirano da voda nije komercijalni proizvod, nego je nasljeđe koje treba čuvati, štititi te se njime mudro i racionalno koristiti. Vodama se upravlja prema načelu jedinstva vodnog sustava i načelu održivog razvitka kojim se zadovoljavaju potrebe sadašnje generacije i ne ugrožavaju pravo i mogućnost budućih generacija da to ostvare za sebe. Upravljanje vodama na planeti treba jasno prilagođavati klimatskim promjenama. Globalna strategija o vodama treba biti briga za ekosustav i osiguranje njegove održivosti na planeti Zemlji. Osnovni je zadatak čovječanstva na planeti da stvori takve uvjete biološke ravnoteže u prirodi na temelju kojih će se ona razvijati u skladu sa zahtjevima ljudske djelatnosti. Vremena je sve manje da se zaustavi destruktivna eksploatacija životne sredine prije nego što se nanesu daljnje nepopravljive štete. Glavni problem leži u činjenici što ljudi troše više pitke vode no što ima raspoloživih zaliha te time potiču zabrinjavajuće pitanje do kada ovo čovječanstvo na planeti Zemlji može opstati.

\section{Literatura}

[1] Burnie, D., Challoner, J., Coyne, C., Harrar, S., McGhee, K. (2015) Zemlja planet ekstrema. Reader's Digest, Mozaik knjiga

[2] Climatica, http://climatica.org.uk/climate-science-information/thehydrosphere-global-water (pristupljeno dana 13.04.2019.)

[3] Franks, F. (2000) Water: A matrix of life. The Royal Society of Chemistry, Cambridge CB4 OWF, United Kingdom

[4] HAZU (2016) Hrvatska prirodna bogatstva i prirodna dobra - zaštita i odgovorni razvoj. HAZU, Tisak Zelina d.d., Zagreb

[5] Laws R.M., Franks, F. (1993) Life at Low Temperatures, Phil. Princeton University Press, Princeton, New York

[6] Litvinoff, M. (2001) Atlas zaštite okoliša. Veliki ilustrirani vodič za skrb o našem planetu, ABC naklada, Zagreb

[7] Lorch, L. (1981) Handbook of Water Purification, McGraw-Hill, London

[8] Kitanović, B. (1979) Planet i civilizacija u opasnosti. Izdavačka radna organizacija privredna štampa Beograd, Beograd

[9] Matas, M., Simončić, V., Šobot, S. (1989) Zaštita okoline danas i sutra. Školska knjiga Zagreb, Zagreb

[10] Nova istraživanja o vodi (2018.) - Na rubu znanosti, (pristupljeno dana 15.02.2019.), https://www.youtube.com/watch?v=2N7FmQ6VYDw

[11] Počuča, N. (2008) Ekohidrologija - zagađenje i zaštita voda. Građevinska knjiga, Budućnost, Zrenjanin

[12] Steel, E.W., Mc Ghee, T.J. (1988) Water Supply and Sewerage, Mc Graw Hill Book Company, London 